IZA DP No. 6506

Labour Supply as a Buffer:

Evidence from UK Households

Andrew Benito

Jumana Saleheen

April 2012 


\title{
Labour Supply as a Buffer: Evidence from UK Households
}

\author{
Andrew Benito \\ Bank of England \\ and IZA \\ Jumana Saleheen \\ Bank of England
}

\section{Discussion Paper No. 6506 \\ April 2012}

IZA
P.O. Box 7240
53072 Bonn
Germany

Phone: +49-228-3894-0

Fax: +49-228-3894-180

E-mail: iza@iza.org

\begin{abstract}
Any opinions expressed here are those of the author(s) and not those of IZA. Research published in this series may include views on policy, but the institute itself takes no institutional policy positions.

The Institute for the Study of Labor (IZA) in Bonn is a local and virtual international research center and a place of communication between science, politics and business. IZA is an independent nonprofit organization supported by Deutsche Post Foundation. The center is associated with the University of Bonn and offers a stimulating research environment through its international network, workshops and conferences, data service, project support, research visits and doctoral program. IZA engages in (i) original and internationally competitive research in all fields of labor economics, (ii) development of policy concepts, and (iii) dissemination of research results and concepts to the interested public.
\end{abstract}

IZA Discussion Papers often represent preliminary work and are circulated to encourage discussion. Citation of such a paper should account for its provisional character. A revised version may be available directly from the author. 
IZA Discussion Paper No. 6506

April 2012

\section{ABSTRACT}

\section{Labour Supply as a Buffer: Evidence from UK Households}

This paper examines labour supply adjustment - both hours worked and participation decisions. We focus on the response of each to financial shocks, employing data from the BHPS. Estimated responses are broadly consistent with models of self-insurance that incorporate labour supply flexibility. The shock reflects several factors including financial wealth and a partner's employment situation. The response is significantly larger for those who change job, consistent with the importance of hours constraints within jobs. The propensity to participate in the labour market also appears to respond to the financial shock but that is somewhat less robust than the hours response.

JEL Classification: J22

Keywords: labour supply, self-insurance

Corresponding author:

Andrew Benito

Goldman Sachs

120 Fleet Street

London EC4A 2BB

United Kingdom

E-mail: abenito.work@gmail.com

\footnotetext{
* The views expressed in this paper are those of the authors, and not necessarily those of the Bank of England. We are grateful to Richard Blundell, Neal Hatch, Hamish Low, Mark Taylor, two anonymous referees and seminar participants at the Bank of England and Bank of Spain for useful comments and discussions.
} 


\section{Introduction}

How do households respond to financial shocks? This general question is central to any discussion of how macroeconomic news affects the outlook for the economy and the appropriate policy response. Such responses, which might include consumer spending and labour supply responses, are also central to discussions of inequality as revealed in consumption and income (Blundell (2009)). Shedding light on the possible use of labour supply as a response to financial news is the aim of this paper.

The 'first generation' of self-insurance models of household saving took labour supply as fixed - for example in the self-insurance model of Deaton (1991) and buffer stock saving model of Carroll (1992). Any adjustment in these models therefore comes through consumer spending. But more recent models relax that fixed labour supply assumption (eg, Low, 2005; Attanasio et al, 2005). These models point clearly to the use of labour supply. That operates both as a means of insuring against income risk, ex ante - with workers supplying less labour when they believe the world (and their labour income) is more stable - and as a means of responding to a given shock, $e x$ post.

This paper considers the use of labour supply as a buffer in an ex post sense - as a response to some financial shock. The source of the shock is not explicit in the data considered, but it is likely to be a broad measure of financial shocks, capturing a range of unexpected changes to income or wealth. Flexible labour supply may also help account for other 'puzzles' in household behaviour. That includes understanding why households work relatively long hours while young - when wages are relatively low - and shorter hours while old, when wages are typically much higher. It could also help rationalise why estimated spending responses to changing asset prices have often seemed 'small' relative to the predictions of a standard life-cycle model (Poterba (2000); French (2000)). An ability to respond through labour supply means less onus need be placed on spending to achieve some adjustment.

While models with flexible labour supply seem to match certain 'ex ante' stylised facts of household behaviour more closely, there is relatively little 
evidence on the use of labour supply as a response to shocks. At the same time, empirical evidence on labour supply and hours worked suggests it is difficult for individuals to change their hours worked. Hours constraints are pervasive and changing jobs is costly (Stewart and Swaffield, (1997), Bryan (2007)). This complicates the likely use of labour supply at the extensive margin of hours worked and places a premium on empirical evidence.

Our results, based on an analysis of data from the British Household Panel Survey (BHPS), point quite clearly to the use of hours worked as a response to financial shocks, and support the use of labour supply as a buffer in response to financial shocks. An important part of our work is to use a financial shock variable that can be constructed from the panel nature of the BHPS (eg, Boheim and Ermisch, 2001; Benito, 2009). Our results confirm the importance of allowing for labour supply flexibility in understanding household behaviour. The results also indicate the importance of changing job as a means of facilitating a significantly larger labour supply response. Effects on hours worked are estimated at being several times larger where the employee changes job; and for those remaining in the same job hours of work responses are at the margins of significance. The results are, therefore, also consistent with the importance of hours constraints within jobs.

The remainder of the paper is organised as follows. Section 2 outlines the theoretical background drawing on recent models of household behaviour with uncertainty and flexible labour supply. The discussion also highlights the likely importance of hours constraints within jobs. Section 3 describes the data drawn from the British Household Panel Survey (BHPS). Section 4 presents estimation results for labour supply adjustment. These estimates are based on panel data methods for hours adjustment and participation decisions and their responses to financial shocks. Section 5 concludes.

\section{Economic Background}

\subsection{Theoretical background}

A relatively small but growing number of theoretical models of household behaviour highlight the use of labour supply as a response to financial news. 
Low (2005) introduces labour supply flexibility into a partial equilibrium life-cycle model with 'self-insurance'. Households accumulate savings partly as a buffer against future labour income uncertainty. The ability to flex labour supply is shown to have the following effects relative to the case with inflexible labour. First, it reduces saving while young. That is because the ability to respond flexibly through additional labour supply to any adverse shock reduces the need to self-insure by accumulating savings beforehand; saving when middle-aged rises. Second, hours of work while young are higher - since individuals accumulate some of their buffer stock of savings against future uncertainty not simply by depressing their spending but also by raising labour supply ahead of that uncertainty. This implication helps resolve the puzzle of labour supply over the life-cycle under which individuals seem to work longer hours while young, despite the fact that their wages are significantly lower. Third, it is shown how greater substitutability between consumption and leisure weakens the precautionary motive as both consumption and hours become more hump-shaped.

The model of French (2005) highlights the effects of uncertainty - about wages and health - on labour supply, while focusing on retirement decisions. In that model households face severe borrowing constraints, being unable to borrow against future labour (or pension) income. Large fixed costs of working are required to fit the profiles for participation and hours worked and that also implies a high responsiveness to wages through retirement behaviour at older ages. The model predicts that labour supply elasticities should be increasing in age.

Bottazzi et al (2007) focus on the role of housing (and debt) and how this affects labour supply decisions in a model with wage and house price uncertainty. Households are subject to a collateral constraint in their secured borrowing decision. Additional labour supply affords one way of relaxing that constraint. In response to a wage shock, it is less costly to adjust labour supply than to change consumption of housing by moving home. This implies that households close to their borrowing constraint will experience a larger labour supply response than those households with more spare borrowing capacity.

Labour supply decisions may of course be made at the household rather than individual-level. Attanasio et al (2005) employ a similar life-cycle 
model to Low (2005) to highlight the possibility that within a household, labour supply may respond to the partner's financial situation (see also Blundell, 2009). Partly simply because there is greater scope for adjustment - with lower average participation rates and hours worked - this response may be larger for women, the case on which Attanasio et al (2005) focus. Similar reasoning suggests the response should be larger among the old, where participation rates are lower.

To summarise, these self-insurance models with flexible labour supply taken together - have generated some supplementary predictions for the labour supply response to a financial shock (usually thought of as a wage shock). First, any effect should be greater for those who are close to their borrowing limit. Second, the effect should be larger among older employees, for whom the elasticity of labour supply is higher. Note that the first prediction may work against this latter prediction - the old are less likely to be credit constrained, having (in general) accumulated assets and do not face as steeply-sloped an earnings profile. Third, the shock may partly reflect the partner's financial situation and shocks to that such as loss of work for the partner. That response may be larger for women than men.

\subsection{Hours constraints}

These theoretical models inevitably abstract from several features that shape labour supply in practice. One such feature is the presence of hours constraints - which a number of studies have highlighted as important.

Stewart and Swaffield (1997) noted that many (manual) employees work hours significantly different to their preferred level, at the prevailing hourly wage. That may make adjustment through labour supply difficult and/or undesirable. Precisely how to interpret these hours constraints is not straightforward, but prima facie they appear inconsistent with the canonical model of labour supply, where individuals work their desired hours or can switch costlessly between jobs with different hours on offer.

In terms of interpreting how some individuals work different hours to what they would like, one possibility is that fixed costs of employment (eg, training or social insurance) may effectively make short-hours unprofitable for the firm. A competitive outcome can then imply workers working more hours than desired but fewer hours than the employer would like. Another 
possibility is that this is a temporary phenomenon and people being 'off their labour supply curve' will be corrected through labour mobility. But deviations from desired hours seem to persist for quite long periods of time suggesting that any costs of mobility must be high (Bryan, 2007). A third alternative possibility is that the standard model of labour supply is wrong in a deeper sense and instead the labour market has monopsonistic features. High costs of worker mobility may effectively confer some monopsony power to employers implying workers are 'bargained off' their labour supply curve (Naylor (2002)).

In terms of understanding how households might respond to a financial shock these models would seem to have a common implication: in practice it may be difficult for employees to raise their hours worked in response to some shocks. An emphasis on hours constraints might offset the previous theoretical prediction of an hours worked, labour supply response to a financial shock. An obvious implication of hours constraints within jobs is that any response should be greater when an employee changes job (Blundell et al, 2008).

\section{Data Description}

\subsection{The Data}

Data are drawn from the British Household Panel Survey (BHPS) for the years 1991 to 2007. The BHPS is an annual, panel-based survey of households in Britain (formally, those living south of Caledonian Canal) beginning in 1991 with a sample of approximately 5,500 households. Individuals join the survey when they form households with one of these original sample members. The BHPS provides detailed information on employment including working hours, incomes, education and standard demographic characteristics. Information on financial positions is more limited. Interviews essentially take place in the autumn of each calendar year.

\section{The financial shock indicator}

Our key measure of a financial shock is constructed in the following way. In each year each individual is asked how do they expect their 'financial situation' to change over the following year; they are also asked how their financial situation changed over the past year. Comparing an individual's experience for the year with what one year previously they had expected for 
that year provides a useful indicator of a financial surprise or shock (eg, Boheim and Ermisch (2001); Benito (2007, 2009)). This has the advantage over using observed outcomes for wages, employment, house prices or anything else that might be related to a shock, that some changes in these outcomes may be expected or even voluntary, and may not therefore reflect the kind of ex post shock of interest.

However, the indicator also suffers the disadvantage that it is not entirely clear what form of shock the 'financial situation' captures. Below, we take an eclectic approach to shedding light on this issue, by examining what factors are related, empirically, to the experience of these shocks. This issue of interpretation is less relevant for two of the key issues that motivate the study: assessing the importance of labour supply flexibility and the role of hours constraints.

The sample employed here is selected on the basis of individuals who are employed, working positive hours in at least two successive years, aged less than 65 in the first year they appear in the panel, and not belonging to the BHPS 'booster' samples undertaken in 1999 and 2001.'

\section{Data description}

Data description proceeds in two stages. First, some proxies for the likely flexibility of hours are presented, based on different types of hours worked (contracted hours, paid and unpaid over-time and second jobs). Second, given its importance to the analysis, additional data description of the financial shock variable is presented. That includes a general data description of the covariates used.

\section{How variable are hours worked?}

Employees may face different adjustment costs for adjusting their hours in different ways. Paid over-time and second jobs are likely to afford greater flexibility - being capable of being changed at low cost - than contractual hours.

\footnotetext{
${ }^{1}$ These booster samples were added for Scotland and Wales in 1999 and Northern Ireland in 2001 in order to facilitate country-level analysis.
} 
The narrowest measure of hours in the BHPS is core, contracted hours normally worked (excluding over-time and meal breaks). The broadest measure is total hours normally worked including over-time (paid and unpaid) and any hours worked in a second job. Between these measures, other definitions include only paid over-time in the main job, paid and unpaid hours in the main job and all remunerated hours (contracted hours plus paid over-time and second job's hours).

How widespread is working 'extra' hours (over contractual hours)? Table 1 shows that one-half of male employees work overtime, either paid or unpaid. In the case of non-manual male employees that is mostly unpaid, although almost $20 \%$ of male, non-manual employees work paid over-time. Among manual workers, almost all overtime is paid overtime. The proportions are a little lower for women. Around $10 \%$ of employed men and women have second jobs.

Quantitatively, how significant are these extra hours worked? Table 1 also indicates the number of 'extra' hours worked relative to their normal contract hours, among those working over-time, paid over-time or second jobs, respectively. The overall impression is that extra hours are quite important - and that includes paid extra hours. Among those working overtime (paid or unpaid) their overtime hours are on average almost onequarter of their main contracted hours. The proportion for paid overtime is around 20-25\%. As noted above, a smaller proportion of people have second jobs than work paid over-time. But having incurred the costs of obtaining an additional job, the hours they allocate to their second jobs are a significant proportion of their main job's hours, particularly for women and average around $20-30 \%$. It is also clear that many individuals work no paid additional hours. Yet, $16 \%$ of employees work extra hours that are at least $20 \%$ of their main contracted hours.

Hours variability over the year is another indicator of scope for hours adjustment. The mean absolute change in total paid hours worked per week is 3.9 , which is over $10 \%$ of average total paid hours. Hours variability is greater for men (4.1 hours) than women (3.7 hours). Larger differences emerge for the private $\mathrm{v}$ public sector comparison (almost a full hour per week) and for the manual $v$ non-manual comparison (1.3 hours). Those that stated they wanted to work different hours see greater hours variability, 
suggesting they are able to act on that preference to some extent. A similar finding for hours constraints is obtained by Boheim and Taylor (2004). Those that experienced a financial shock exhibit slightly greater hours variability, consistent with their wanting to change hours in response to financial surprises and being able to act on that to a degree.

The single most important characteristic for (longitudinal) hours variability over time is whether the individual changed job in the past year (Blundell et al, 2008). The mean absolute change in hours for those that change job of 6 hours per week compares to an equivalent figure for those that did not change job of 3.3 hours per week. ${ }^{2}$

So to summarise, hours variability is greater among men, manual workers in the private sector, those that had wanted to work different hours, experienced a financial shock and, quite crucially, changed job. These characteristics can of course be combined. As one example, for those who changed job, experienced a negative financial shock and also preferred to work more hours (the year before), the mean absolute change in hours over a year is close to 10 hours per week (based on a sample of 421 individuals).

\section{Who experiences a financial shock?}

In the raw data, those experiencing a negative shock are on average less highly-educated, have a lower hourly wage (which may proxy their human capital), have lower wage growth, are more likely to have separated from their partner in the past year; they are a similar age and experience similar house price appreciation (on the self-reported measure used here) to other individuals. $^{3}$

As a further exercise in data description, Table 2 reports results from probit models for the experience of an adverse financial shock as a function of these characteristics. ${ }^{4}$ This helps control for associations among the covariates in seeing how the experience of a negative shock is related to individual and household characteristics in the raw data.

\footnotetext{
${ }^{2}$ A job change can occur either at the same employer or by changing employer. Using the BHPS job history files would allow us to distinguish between these two types of job move, although preliminary analysis indicated that would involve the loss of around twothirds of the sample so that distinction was not pursued.

${ }^{3}$ See Benito and Saleheen (2011) for further description of the raw data.

${ }^{4}$ Since this is intended simply as an exercise in data description, these probit models do not control for random effects.
} 
Having experienced an adverse financial shock is more likely for those who are young, have low household income and have had low income growth over the year. Public sector workers are less likely to experience an adverse financial shock. A higher hourly wage and higher wage growth on the year are similarly negatively related to the propensity to experience a shock, and are highly statistically significant. There is only modest evidence suggesting that, having controlled for wage, income and other terms, being degreeeducated is associated with a lower incidence of experiencing a negative financial shock. A financial shock is significantly more likely to be recorded by someone whose partner lost their job in the past year.

Among men, for the 1991 to 2007 sample (column 1) the probability of having a negative shock is raised by 0.092 if the partner loses their job (evaluated at the means of the data) while for women it is raised by 0.164 (column 3). These coefficients are well-determined, with robust t-ratios in excess of 5. Since the mean proportion that report a negative financial shock is $0.27(0.28)$ for men (women), the partial effect of a partner having lost their job is large - and especially so for women.

In terms of links with asset prices, there is little or no suggestion that how the house value has varied over the year is related to a financial shock. ${ }^{5}$ On that basis, households would appear not to attach much weight on how their house price has varied relative to what they might have expected in assessing how their financial situation has surprised them. ${ }^{6}$ Data on pension status are rather limited in the BHPS. There is some evidence that those with a defined benefit (DB) pension are less likely to be recorded as having experienced a shock, at least among men (column 2).

\section{Participation decisions}

Table 3 presents average participation rates before and after experiencing a financial shock. The raw data are consistent with a positive labour supply response following a negative financial shock for women - but not for men. Average participation rates seem untrended for both groups prior to the year of the shock. Following the adverse shock, the average participation

\footnotetext{
${ }^{5}$ This suggests our financial shock term is unlikely to pick up the effects of house price shocks on labour supply - an effect on which Henley (2004) focuses.

${ }^{6}$ That may be because they plan to remain in the same home for many years, in which case there is little net financial gain from house price appreciation - and particularly if they plan to move to a similarly sized next home. Those planning on trading down (up) soon would be the major winners (losers) from house price gains.
} 
rate for women rises by around $1.7 \mathrm{pp}$, while for those women not experiencing the shock it falls marginally. A raw difference in differences estimate of the effect of the financial shock on participation rates puts this at 0.023 for women but only 0.004 for men.

There are high rates of persistence in labour force participation. That persistence seems lower for those that experience a negative financial shock, however. Among men that experience no shock between successive years are outside the labour force, $\mathbf{7 . 6 \%}$ of them transit to become participants in the following year. That proportion rises to $22.8 \%$ among those men who experience a negative financial shock (in the previous year). A similar pattern obtains among women. While $10.4 \%$ of non-participants that experience no financial shock transit to participation in the following year, that proportion rises to $\mathbf{2 5 . 3 \%}$ among women that experience a negative financial shock.

Some survey evidence seems consistent with the likely importance of labour supply responses - at least in some circumstances. A survey by the Building Societies Association of a sample of households that had fallen into mortgage arrears but who corrected those arrears enquired how they had managed to do that. Labour supply responses - working longer hours and taking a second job - feature strongly among these responses, and indeed feature more prominently than the 'reduced spending' response. ${ }^{7} \mathrm{We}$ now aim to confront that hypothesis with data more formally.

\section{Estimation and Results}

Estimation methods for labour supply adjustment cover both changes in hours worked and labour force participation. Heckman (1993) emphasises the importance of distinguishing the two types of effect. Heckman (1993) also notes the traditional view that the participation margin is a more important margin for labour supply adjustment than is that of hours.

\footnotetext{
${ }^{7}$ When large financial pressures need correcting in the short-term - such as falling into mortgage arrears - a labour supply response at the extensive margin (hours worked) seems more likely than when adjustment can be corrected over the medium-term, such as in response to weaker asset prices.
} 


\subsection{Regression-adjusted difference-in-differences estimator for hours worked}

A standard difference-in-differences estimator that compares the change in experience of treatment and control groups can be implemented in a standard least squares regression applied to panel data (eg, Stewart and Swaffield, 2008). By the same token, this means that the effect of some 'shock' can be understood in a difference-in-differences framework. ${ }^{8}$

This estimator is designed to address the question: how would hours of work have changed for those that experienced a financial shock had they not experienced a financial shock, and by how much did their actual labour supply evolve differently from that? This is the 'treatment effect on the treated'. The standard difference in differences estimator takes the change in average hours worked (per week) of those affected by the shock and deducts the change in average hours worked of the comparison group, those who do not experience a financial shock. This can be implemented as a standard linear regression model (that being a model for the conditional mean of the dependent variable).

As with any difference-in-differences estimation, there are two key identifying assumptions. First, those individuals subject to the financial shock should not be prone to a different trend in hours worked to those that do not experience the shock. Second, there should be no 'spillover' effects from the labour supply choices of those experiencing the shock to those that do not experience the shock. Under these assumptions, least squares estimation provides an unbiased estimate of the average effect of a financial shock on labour supply (hours) of those affected by the shock.

It is also assumed that experiencing a financial shock is not correlated with factors that are related to labour supply decisions. Or rather, given the regression-adjusted nature of the difference-in-differences estimator it is assumed these are controlled for by the inclusion of the additional controls (eg, Stewart, 2004).

\footnotetext{
${ }^{8}$ Stewart and Swaffield (2008) and Blundell et al (2008) examine the effects of certain policy interventions (the national minimum wage and changes in in-work benefits, respectively) on hours worked. But the framework can be borrowed to estimate the effect of any shock that is assumed to affect one group and not another.
} 


\subsection{Dynamic random effects probit models for participation decisions}

We also examine the propensity to participate in the labour market and how this is affected by a financial shock. Our estimating equation consists of:

$$
y_{i t}=1\left\{\gamma y_{i t-1}+X_{i t}^{\prime} \beta+\alpha_{i}+u_{i t}>0\right\}
$$

where ' $i$ ' indexes individuals, $i=1,2 . . \mathrm{N}$ and ' $t$ ' indexes years $t=1992$, 1993..2007. $1\{\mathrm{~A}\}$ is the indicator function for the event ' $\mathrm{A}$ ', so that an individual is either observed participating in the labour market (as an employee, self-employed or unemployed) or is outside the labour force. ${ }^{9}$ The model includes a lagged dependent variable, $y_{\mathrm{it}-1}$, with associated coefficient ' $\gamma$ ' indicating the degree of state dependence in the participation decision. A vector of explanatory variables $X$ have associated parameter vector, $\beta$. The regressor set includes a set of year dummies to control for common macroeconomic effects. The financial shock terms are also included in $X$, as well as other 'taste shifters'. The model includes a set of individual-specific effects controlling for unobserved heterogeneity, $\alpha_{i}$. In the random effects model these are assumed $\alpha_{\mathrm{i}} \sim \mathrm{N}\left(0, \sigma_{\alpha}^{2}\right)$ with the error term $u_{\mathrm{it}}$ assumed to be (standard) normally distributed and serially uncorrelated. ${ }^{10}$ The individual-specific heterogeneity and error term are assumed uncorrelated with each other and with the covariates, $X$ and $y_{\text {it-1. }}$.

The inclusion of the lagged dependent variable $\left(y_{i t-1}\right)$ alongside unobserved heterogeneity $\left(\alpha_{i}\right)$ generates an 'initial conditions problem' if, as seems likely, the two are correlated. Heckman (1981) presents an estimator that deals with this issue but that requires convincing exclusion restrictions. An alternative estimator proposed by Wooldridge (2005) is simpler to implement, does not require exclusion restrictions and has been shown to provide similar results to the Heckman estimator in both small and large samples (see Arulampalam and Stewart, 2009). Our results focus on the Wooldridge (2005) estimator. ${ }^{11}$

\footnotetext{
${ }^{9}$ The following labour market states are all classified as outside the labour force: retired, family carer, full-time student, long-term sick or disabled, on maternity leave, on a government training scheme or the residual category 'something else'.

${ }^{10}$ Stewart (2006) considers the case where there is serial correlation in the error term

${ }^{11}$ Cappellari and Jenkins (2009) employ the Wooldridge estimator while studying the dynamics of social assistance benefit receipt.
} 
Conventional models for labour supply reviewed by Blundell and MaCurdy (1999) consider (log) hours as a function of an own-wage term and unearned income (typically proxied by the partner's labour income in the case of married women as well as interest income). These models rarely include any direct measure of financial (or housing) wealth. Based on the results reported above, our measure of a financial shock appears related to financial wealth surprises (eg, through the DC versus DB pension terms) which these labour supply models rarely capture. Our approach for hours worked, following that of Blundell et al (2008) and Stewart and Swaffield (2008), also has the advantage of being much more straightforward to estimate and interpret than those models. ${ }^{12}$ However, compared to a standard labour supply model with earned and unearned income effects, our models are clearly reduced-form; the financial shock term will pick up both of these effects, along with others that are related to wealth and changes in household structure. A small number of studies have looked at the effects of wealth on labour supply, focusing on the effects of financial 'windfalls'. These studies generally find that receiving positive windfalls to one's wealth (eg, associated with a lottery) reduce labour supply. This also offers an alternative approach to the one pursued here. Henley (2004) presents what would appear to be the sole UK study of how wealth windfalls affect labour supply. ${ }^{13}$

\subsection{Estimation results}

Regression-adjusted difference-in-differences for hours worked

Table 4 presents results from the regression-adjusted difference-indifferences estimator for hours worked. The coefficients reported in the Table indicate the change in weekly hours worked for a negative financial shock and a positive financial shock - both relative to the base group of no shock, that is, one's financial situation reported as similar to what one expected a year before.

There are two key results. First, there is evidence in favour of the key prediction that employees respond to financial shocks by adjusting labour supply. Men affected by a negative financial shock tend to increase their

\footnotetext{
${ }^{12}$ Blundell and MaCurdy (1999) highlight difficulties in interpreting many labour supply elasticities owing to the range of functional forms used.

${ }^{13}$ Some of the windfalls included by Henley (2004), such as redundancy payments, may be related to participation decisions for reasons unrelated to how they affect the marginal utility of wealth.
} 
hours worked (relative to no shock). Among women, a negative shock is associated with a significant increase in hours relative to a positive shock, although this is not significant relative to the base group of no shock. For women, a stronger result is that in response to a positive financial shock, they reduce hours worked.

Second, changing job is important for facilitating that labour supply response. An employed man experiencing a negative financial shock that changes his job experiences an increase in hours worked by 1.2 hours per week on average. A man who does not change job raises his hours by much less, only about 15 minutes per week, although still statistically significant. Among women, the effects of shocks are also more significant for job changers than those who do not change job. For women, that comes through more in the form of reducing hours in response to a positive financial shock - and generates a large effect at around 1.5 hours per week among job changing women experiencing a positive shock. The results suggest that changing job within a firm is a strongly related to hours adjustment. That is also true for those job changes that involve a change of employer - at least for men.

How does labour supply adjustment differ by age? We split the sample at around sample median age, 40, and report results separately for the two sub-samples. The results suggest that the relatively young are more flexible in adjusting their hours worked. Among other things, the young may differ by having less firm-specific and job-specific human capital. This may increase their flexibility to respond to changes to their hours preferences, although adding a control for a job move does not change the pattern of results very much.

We examined the robustness of these results by changing the set of control variables. The addition of additional controls for changes in household composition (ie, a change in marriage status, birth of a child or a child reaching primary school age) made next to no difference to the results cited in Table 4.

A prediction of the Bottazzi et al (2007) model is that mortgage-holders face higher adjustment costs (to changing mortgage-related outgoings) in the face of a wage shock and this makes them more likely to adjust by 
raising their labour supply. This does not find empirical support in our regressions. Among the sample of men we find larger labour supply responses for those without a mortgage, with an estimated response of 0.779 hours in terms of total paid hours compared to an equivalent response of 0.346 hours, among those with a mortgage.

Among those without a mortgage, around two-thirds are renters with onethird owning their property outright. These may be quite different groups, particularly in terms of their likelihood of being liquidity constrained, and while renters have precommitted rental payments, those who own outright do not. So those who own outright may be a better comparison group for those with a mortgage under the Bottazzi et al (2007) model. Estimating the same hours adjustment equations for those who own their properties outright again fails to offer much supportive evidence. The estimates are less well-determined, likely reflecting the smaller sample size and are generally borderline significant. But the point estimates of the responses for the group of those who own their property outright are generally a little larger in absolute magnitude than for the group of mortgagors.

The model of Bottazzi et al (2007) predicts a highly non-linear response between debt and labour supply responses. The largest responses should be among those that are closest to exhausting their borrowing capacity being close to their borrowing limit. Such borrowing capacity is likely to be related to the loan-to-value ratio on the property. ${ }^{14}$ Table 5 reports results that try to assess this hypothesis, considering whether those mortgagors with high loan-to-value ratios experience greater labour supply responses than those with lower loan-to-value ratios (but who have a mortgage). The median loan-to-value ratio of those with a mortgage is 0.46 and we use this as the threshold to define the two samples. We are not able to uncover evidence that those with higher loan-to-value ratios, that have smaller equity cushions to borrow against, have any larger labour supply responses.

Employing the loan-to-income ratio as an indicator of borrowing capacity generates a similar pattern of results. There is little evidence suggesting that those with higher loan-to-income ratios - perhaps with less of an

\footnotetext{
${ }^{14}$ See Benito (2006a) for an analysis of how the collateral constraint affects the housing market. Benito and Mumtaz (2009) present evidence of how the collateral constraint (through the current loan-to-value ratio) affects spending plans consistent with liquidity constraints operating on some households.
} 
untapped marginal borrowing capacity - respond by raising their hours worked to a greater extent.

As an alternative indicator of financial distress as regards housing payments, we consider whether the household reports that they have had problems paying for their housing (whether owned or rented) over the year. A relatively small sample (around 1,100 men and 1,400 women) reports payment difficulties on this measure. This makes isolating a well-determined coefficient more difficult than for the larger sample of those reporting no payment difficulties. That point notwithstanding, the pattern does not lend any general support to the idea that those with payment difficulties - that might find it more difficult to extend their borrowing further - respond by raising their labour supply to a greater extent than other households. There is evidence, however, that those facing mortgage payment problems are less likely to change job, perhaps because it is also less likely that they will move home. Given the importance of changing jobs as a way of altering hours worked, then this may prevent these households for making the labour supply adjustment they would otherwise like to make.

As Bottazzi et al (2007) highlight, in cross-section homeowners work longer hours and that seems to hold even after controlling for how availability of mortgage finance might differ between homeowners and non-homeowners. Our evidence points to little significant difference between the two groups' responses to financial surprises in terms of their hours worked. That might suggest that longer hours worked of homeowners might emerge as a more long-term response to financial pressures.

\section{Hours preferences}

Many employees appear to work hours that differ from their desired hours at the prevailing wage (Stewart and Swaffield (1997)). Labour supply responses in terms of hours worked seem likely to depend on the individual's hours relative to their desired hours. Those who initially wanted to work longer hours seem more likely to respond to a negative financial shock by raising their hours worked. Those who initially wanted to work longer hours might find their desired hours closer to desired after being adversely affected by a financial shock and not change their hours. 
We estimated similar change in hours equations separately according to stated preferences over hours worked. The pattern of results confirms our prior. Those who declare that they had wanted to work longer hours are estimated to experience the largest positive change in hours in response to a negative shock, irrespective of whether they change job or not. The term for the negative financial shock term attracted a coefficient (robust t-ratio) for men of 1.163 (2.14) paid hours and 0.962 (1.98) hours among women. For those who wanted to work fewer hours the equivalent coefficients are 0.092 and -0.100 , respectively and both insignificant. Those who were working similar hours to their desired level, see an intermediate response, although one that is estimated in a more well-determined way, likely reflecting the larger sample sizes in this group.

We conclude that the hours worked response will depend on where an individual's hours are relative to their desired hours. The overall pattern is consistent with labour supply preferences responding as expected to a financial shock. ${ }^{15}$

As a robustness check on our results, we also applied a propensity score matching approach to the estimation. This delivered very similar findings to the least squares analysis of the difference in differences estimator for hours worked reported above.

\section{Dynamic random effects probit models}

Table 6 reports estimation results from dynamic random effects (RE) probit models for the propensity to participate in the labour market. The set of regressors is similar to that of Hyslop (1999) who examined married women's labour supply in the United States. We extend that regressor set for indicators of health status, which prove highly significant, and for the financial shock terms. The results reported in Table 6 indicate the standard RE probit model under the assumption that the initial conditions $\left(y_{i 0}\right)$ are exogenous. Subsequent results in Tables 7 and 8 apply the Wooldridge estimator which conditions on those initial observations of the individual for participation.

\footnotetext{
${ }^{15}$ Separately, we have also considered household-level hours, thereby redefining the unit of observation to total hours of the household, taking into account any change in the number of employees. These results confirm the pattern found above and if anything strengthen that view, particularly if the financial shock variable reflects any member of the household having experienced a financial shock.
} 
Before focusing on labour supply as a buffer, there are several other interesting results. First, there is consistent evidence of state dependence, as indicated by a quantitatively large and statistically significant lagged dependent variable. That obtains after controlling for unobserved heterogeneity through the random effects as well as personal characteristics. As expected, the estimated degree of state dependence falls significantly when we control for initial conditions (Table 7) - but state dependence remains statistically significant and quantitatively large throughout. Second, the terms for individual characteristics are intuitive. Those with higher levels of education are more likely to be participants, both for men and women, consistent with education raising the returns to participation. ${ }^{16}$

Third, turning to the role of the financial shocks, there is significant evidence that individuals respond to positive and negative financial surprises by adjusting their labour supply at the extensive margin. That estimated effect obtains after controlling for state dependence and personal characteristics. Without controlling for initial conditions (Table 6), among men an adverse financial shock is estimated to raise the predicted probability of participating in the labour market by 0.014 (t-ratio=3.13) relative to the case of no financial shock. Among women, the equivalent marginal effect associated with an adverse financial shock is to raise the participation probability by 0.025 (t-ratio=3.21). The role for financial surprises is further highlighted by comparing the effect to that associated with a positive financial surprise which, again relative to the omitted group of no financial surprise, lowers participation rates for both men and women.

That finding is somewhat sensitive to whether we control for initial conditions using the Wooldridge (2005) Conditional Maximum Likelihood (CML) estimator. In Table 7, while the estimates that control for initial conditions, state dependence and unobservables generate a statistically significant coefficient on the negative shock term, adding the list of personal controls drives the financial shock terms to insignificance - for both men and women. In fact, it is the inclusion of the age controls that drives the negative financial shock term to insignificance. This seems to reflect the fact that the young face more risk, and with it a greater incidence of negative

\footnotetext{
${ }^{16}$ Table 11 reports marginal effects calculated by normalising on the error variance of the error term $\sigma_{u}$ (see Arulampalam (1999) for a discussion).
} 
shocks, than do older age groups. ${ }^{17} \mathrm{~A}$ related possibility is that the young tend to be less risk averse and so are more likely to experience negative shocks (and to be more mobile). It is not entirely clear that one should control for that particular role associated with age, even though there may be other good reasons for controlling for age.

In column 7 we consider one additional experiment in the sample of married women. We have already shown that the negative financial shock in part picks up variation induced by a partner losing their job. In column 7 we consider directly evidence for an added worker effect, associated with whether a woman enters the labour force as their partner loses his job. We find little evidence in support of this hypothesis. ${ }^{18}$

How does this participation response to the financial shock vary by age? The young might be better able to flex labour supply (eg, by moving geographically) but against that, older workers have lower participation rates in general giving them greater scope to adjust participation, for example by delaying retirement. We estimate separate results for a relatively young age group - those aged under 35 in the first survey year they appear in the sample - and a relatively old age group - those aged 45 or over. Among both men and women the response to financial shocks is estimated to be stronger among the young, highlighted by a significantly negative participation response to a positive financial shock.

The model of Bottazzi et al (2007) suggests that those with less borrowing capacity have a greater tendency for labour supply response through participation. In their model that response occurs predominantly through the participation decisions of (married/cohabiting) women. ${ }^{19}$ In Table 8, we report results obtained from the Wooldridge estimator that control for initial conditions for a sample of married women. We estimate separate models according to balance sheet characteristics of the household.

\footnotetext{
${ }^{17}$ The incidence of negative shocks is 0.31 among those aged under $30 ; 0.30$ for ages $30-39 ; 0.29$ for ages $40-49 ; 0.27$ for ages $50-59$ and 0.20 for ages $60+$. See Benito (2006b) for a study showing how income uncertainty, specifically risk of job loss, affects consumer spending.

${ }^{18}$ Stephens (2002) notes that the literature has generally indicated a small or negligible added worker effect from married women's labour supply. That is interpreted as consistent with spells of unemployment among husbands being transitory. Stephens (2002) finds somewhat stronger evidence for the United States based on a distinction between voluntary and involuntary job displacement.

${ }^{19}$ For the same reason, theoretical models of self-insurance with flexible labour supply focus on (married) women's labour supply (eg, Attanasio et al, 2005; Bottazzi et al (2007)).
} 
Columns 1 to 3 consider different types of housing tenure status. These results are most favourable to the Bottazzi et al (2007) model. The participation response is estimated to be largest for those that are owneroccupiers and in particular for those households who hold a mortgage. Across the three samples, this is the only group where the participation propensity of married women responds significantly to a financial shock.

Using the loan-to-value ratio as a (inverse) measure of unused borrowing capacity is considered in column 4 to 6 of Table 8. These results are less favourable to the Bottazzi et al (2007) model. The groups of households with lower loan-to-value ratio, and higher borrowing capacity, are more likely to respond through a higher participation propensity of the woman.

Bottazzi et al (2007) emphasise a strong non-linearity in the labour supply response, with the marginal response being stronger at particularly high levels of debt. This hypothesis attracts little direct support. The group with a loan-to-value ratio of $\mathbf{0 . 6 5}$ or above has a similar responsiveness to groups with slightly less debt. It may be that loan-to-value ratios are more difficult to measure than the simple characteristic of housing tenure status. Another possibility more favourable to the model of Bottazzi et al (2007) is that we are not able to consider the highest loan-to-value ratios at which their implication emerges owing to insufficient sample sizes.

Overall, the results support the idea that the indebted as a group experience a stronger labour supply response to financial shocks at the participation margin. That finding was not apparent in terms of hours of work responses among the employed. And there is less support for the Bottazzi et al (2007) implication that this response should be still stronger among those with particularly high levels of indebtedness.

\section{Conclusions}

Labour supply may offer an important means for households to adjust to financial shocks. Recent models of self-insurance with flexible labour supply emphasise this response. This paper has examined that labour supply response using data from the BHPS for the period 1991 to 2007. 
Labour supply responses might apply at both the extensive (hours) and intensive (participation) margins. The paper has examined both. An important constraint influencing households' hours response to financial shocks is the hours constraints they face. We demonstrate, however, that the incidence of paid over-time - applying to around one-third of men and one-fifth of women employees - and second jobs - held by around 1 in 10 employees - suggest that many individuals are likely able to adjust their hours worked at relatively low cost, should they wish.

Nonetheless, our results suggest that changing job greatly facilitates a larger hours adjustment to labour supply. We find significant evidence of a labour supply response to a financial shock through hours worked. But that response is essentially restricted to those who change job. It is also significantly larger for those who were not already working longer hours than they desired. Such results are consistent with hours constraints placing an important constraint on many workers' scope to adjust their labour supply at the intensive margin.

Participation decisions also appear to respond to financial surprises. These responses hold after controlling for state dependence, individual-specific heterogeneity, initial conditions and a range of personal characteristics, but are sensitive to the decision of controlling for age or not. Overall, the pattern of results does not provide much support for the conventional wisdom - although largely based on earlier sample periods - that most labour supply responses come through the extensive margin of participation rather than the intensive margin of hours worked by the employed.

Our results indicate that the labour supply response may also be related to a household's balance sheet position. There was, however, relatively little evidence that labour supply adjustment is strongly related to the household's level of indebtedness. Further evidence on this issue would clearly be welcome. There might be added value from deriving that evidence from a time when balance sheets were likely to have played a more 'active' role in affecting credit conditions. The sample period considered here - during which credit conditions were relatively easy and perhaps progressively relaxed - might be one reason why balance sheets were not found to interact strongly with labour supply responses. 
Table 1: Scope for hours flexibility

\begin{tabular}{l|cc|cc}
\hline & \multicolumn{3}{|c}{ Male } \\
& $\begin{array}{c}\text { Manual } \\
\mathrm{N}=15,386\end{array}$ & $\begin{array}{c}\text { Non-manual } \\
\mathrm{N}=19,692\end{array}$ & $\begin{array}{c}\text { Manual } \\
\mathrm{N}=6,079\end{array}$ & $\begin{array}{c}\text { Non-manual } \\
\mathrm{N}=30,675\end{array}$ \\
\hline Works over-time & 0.571 & 0.558 & 0.323 & 0.401 \\
Works paid O/T & 0.528 & 0.172 & 0.289 & 0.165 \\
Has second job & 0.081 & 0.089 & 0.119 & 0.101 \\
& \multicolumn{5}{|c}{} \\
\hline Average hours worked -ratio of extra to main hours for those working extra hours & \\
\hline Over-time & 0.250 & 0.238 & 0.264 & 0.237 \\
Paid over-time & 0.252 & 0.200 & 0.268 & 0.241 \\
Second job & 0.187 & 0.179 & 0.384 & 0.300 \\
\hline
\end{tabular}

Note: ratio of extra to main hours takes each category of extra hours individually. 
Table 2: Propensity for Negative Shock

\begin{tabular}{|c|c|c|c|c|}
\hline & \multicolumn{2}{|c|}{ Male } & \multicolumn{2}{|c|}{ Female } \\
\hline & [1] & [2] & [3] & [4] \\
\hline \multicolumn{5}{|l|}{ Personal characteristics } \\
\hline Age* & $-0.184(-4.90)$ & $-0.215(-4.04)$ & $-0.279(-7.69)$ & $-0.317(-6.25)$ \\
\hline Degree-educated & $-0.011(-0.90)$ & $-0.036(-1.52)$ & $-0.025(-2.01)$ & $-0.047(-2.27)$ \\
\hline A-levels & $0.010(0.83)$ & $0.017(0.90)$ & $-0.029(-2.48)$ & $-0.029(-1.66)$ \\
\hline \multicolumn{5}{|l|}{ Job characteristics } \\
\hline manual & $-0.001(-0.16)$ & $-0.004(-0.30)$ & $-0.004(-0.31)$ & $-0.009(-0.58)$ \\
\hline Public sector & $-0.015(-1.50)$ & $-0.003(-0.13)$ & $-0.007(-0.83)$ & $-0.002(-0.13)$ \\
\hline Hourly wage* & $-0.143(-1.84)$ & $0.092(0.66)$ & $-0.344(-3.77)$ & $-0.191(-1.26)$ \\
\hline Real wage growth & $-0.121(-5.84)$ & $-0.157(-5.31)$ & $-0.032(-1.89)$ & $-0.081(-3.42)$ \\
\hline DC pension & & $-0.009(-0.30)$ & & $0.023(0.70)$ \\
\hline DB pension & & $-0.057(-2.23)$ & & $-0.031(-1.26)$ \\
\hline \multicolumn{5}{|l|}{ Household characteristics } \\
\hline Real hhold income growth & $-0.076(-3.84)$ & $-0.075(-2.67)$ & $-0.084(-5.87)$ & $-0.074(-3.66)$ \\
\hline Partner lost job & $0.117(5.59)$ & $0.108(3.14)$ & $0.174(5.51)$ & $0.098(2.06)$ \\
\hline Became divorced & $0.127(2.72)$ & $0.065(0.88)$ & $0.251(6.87)$ & $0.250(4.62)$ \\
\hline House price growth & $0.007(0.19)$ & $0.067(1.24)$ & $-0.032(-0.97)$ & $-0.071(-1.43)$ \\
\hline Year dummies & Yes & Yes & Yes & Yes \\
\hline Actual proportion & 0.273 & 0.290 & 0.244 & 0.248 \\
\hline Predicted proportion & 0.268 & 0.284 & 0.241 & 0.251 \\
\hline Maximum likelihood & $-7,105.03$ & $-3,031.57$ & $-6,718.01$ & $-3,071.66$ \\
\hline Observations & 12,299 & 5,118 & 12,410 & 5,607 \\
\hline
\end{tabular}

Note: Table shows the marginal effects associated with maximum likelihood probit estimates of experiencing a negative financial shock (robust t-statistics in parentheses). The samples with the DC pension terms are restricted to 2001 and 2005 surveys, where these data are available. * indicates coefficient multiplied by 100 . 
Table 3: Average participation probabilities

\begin{tabular}{|c|c|c|c|c|c|c|c|c|c|c|c|c|}
\hline & \multicolumn{4}{|c|}{ Male } & \multicolumn{4}{|c|}{ Female } & \multicolumn{4}{|c|}{ Married Women } \\
\hline & $\begin{array}{c}\text { Negative } \\
\text { shock }\end{array}$ & $\begin{array}{c}\text { No } \\
\text { Negative } \\
\text { shock } \\
\end{array}$ & $\begin{array}{c}\text { Positive } \\
\text { shock }\end{array}$ & $\begin{array}{c}\text { No } \\
\text { Positive } \\
\text { shock }\end{array}$ & $\begin{array}{l}\text { Negative } \\
\text { shock }\end{array}$ & $\begin{array}{c}\text { No } \\
\text { Negative } \\
\text { shock } \\
\end{array}$ & $\begin{array}{c}\text { Positive } \\
\text { shock }\end{array}$ & $\begin{array}{c}\text { No } \\
\text { Positive } \\
\text { shock } \\
\end{array}$ & $\begin{array}{l}\text { Negative } \\
\text { shock }\end{array}$ & $\begin{array}{c}\text { No } \\
\text { negative } \\
\text { shock }\end{array}$ & $\begin{array}{c}\text { Positive } \\
\text { shock }\end{array}$ & $\begin{array}{c}\text { No } \\
\text { Positive } \\
\text { shock } \\
\end{array}$ \\
\hline \multicolumn{13}{|l|}{$\begin{array}{l}\text { Years relative to } \\
\text { shock }\end{array}$} \\
\hline$t-4$ & 0.838 & 0.794 & 0.824 & 0.802 & 0.671 & 0.646 & 0.702 & 0.642 & 0.670 & 0.653 & 0.709 & 0.645 \\
\hline$t-3$ & 0.839 & 0.794 & 0.836 & 0.800 & 0.663 & 0.649 & 0.719 & 0.637 & 0.665 & 0.655 & 0.724 & 0.641 \\
\hline$t-2$ & 0.840 & 0.793 & 0.833 & 0.801 & 0.668 & 0.648 & 0.710 & 0.640 & 0.669 & 0.653 & 0.719 & 0.643 \\
\hline$t-1$ & 0.836 & 0.795 & 0.847 & 0.797 & 0.665 & 0.649 & 0.716 & 0.639 & 0.663 & 0.655 & 0.725 & 0.642 \\
\hline$t=0$ & 0.830 & 0.798 & 0.860 & 0.795 & 0.661 & 0.650 & 0.741 & 0.633 & 0.661 & 0.656 & 0.749 & 0.636 \\
\hline$t+1$ & 0.841 & 0.794 & 0.850 & 0.797 & 0.676 & 0.645 & 0.711 & 0.640 & 0.676 & 0.651 & 0.715 & 0.645 \\
\hline$t+2$ & 0.840 & 0.794 & 0.854 & 0.796 & 0.683 & 0.643 & 0.710 & 0.641 & 0.689 & 0.647 & 0.712 & 0.646 \\
\hline$t+3$ & 0.840 & 0.794 & 0.853 & 0.797 & 0.683 & 0.643 & 0.706 & 0.642 & 0.691 & 0.647 & 0.712 & 0.646 \\
\hline$t+4$ & 0.845 & 0.792 & 0.843 & 0.799 & 0.695 & 0.639 & 0.694 & 0.645 & 0.696 & 0.645 & 0.712 & 0.647 \\
\hline Avg $t-4-t-1$ & 0.838 & 0.794 & 0.835 & 0.800 & 0.667 & 0.648 & 0.712 & 0.640 & 0.667 & 0.654 & 0.719 & 0.642 \\
\hline Avg $t+1-t+4$ & 0.842 & 0.794 & 0.850 & 0.797 & 0.684 & 0.643 & 0.705 & 0.642 & 0.688 & 0.648 & 0.713 & 0.646 \\
\hline $\begin{array}{l}\text { Difference } \\
\text { relative to no } \\
\text { shock }\end{array}$ & 0.004 & & 0.018 & & 0.023 & - & -0.009 & - & 0.028 & & -0.012 & \\
\hline
\end{tabular}


Table 4: Effect of financial shocks - Regression-adjusted difference-in-differences estimates

\begin{tabular}{|c|c|c|c|c|}
\hline & \multicolumn{2}{|c|}{ MALE } & \multicolumn{2}{|c|}{ FEMALE } \\
\hline & $\begin{array}{l}\text { Total paid hours - } \\
\text { main job }\end{array}$ & $\begin{array}{l}\text { Total paid hours - } \\
\text { including second job }\end{array}$ & $\begin{array}{l}\text { Total paid hours - } \\
\text { main job }\end{array}$ & $\begin{array}{l}\text { Total paid hours - } \\
\text { including second job }\end{array}$ \\
\hline $\begin{array}{l}\text { Diff-in-diff with } \\
\text { control vector }\end{array}$ & $n=23,373$ & $n=23,135$ & $n=24,093$ & $n=23,861$ \\
\hline Negative shock (t-1) & $0.444(3.93)$ & $0.474(4.07)$ & $0.273(2.56)$ & $0.272(2.42)$ \\
\hline Positive shock (t-1) & $-0.047(-0.38)$ & $-0.034(-0.27)$ & $-0.293(-2.67)$ & $-0.430(-3.78)$ \\
\hline \multicolumn{5}{|c|}{ ALTERNATIVE SAMPLES (with control vector) } \\
\hline Changed job & $n=4,941$ & $n=4,891$ & $n=4,962$ & $n=4,915$ \\
\hline Negative shock (t-1) & $1.311(4.07)$ & $1.237(3.76)$ & $0.452(1.42)$ & $0.271(0.83)$ \\
\hline Positive shock (t-1) & $0.743(2.01)$ & $0.782(2.12)$ & $-1.116(-3.14)$ & $-1.388(-3.86)$ \\
\hline Did not change job & $N=16,486$ & $N=16,318$ & $N=17,084$ & $N=16,921$ \\
\hline Negative shock (t-1) & $0.160(1.37)$ & $0.217(1.77)$ & $0.168(1.58)$ & $0.231(2.01)$ \\
\hline Positive shock (t-1) & $-0.178(-1.34)$ & $-0.169(-1.23)$ & $-0.108(-1.01)$ & $-0.199(-1.76)$ \\
\hline Changed employer & $\mathrm{n}=3,521$ & $\mathrm{~N}=3,483$ & $\mathrm{~N}=3,503$ & $\mathrm{~N}=3,464$ \\
\hline Negative shock (t-1) & $1.488(3.72)$ & $1.402(3.46)$ & $0.688(1.75)$ & $0.606(1.51)$ \\
\hline Positive shock (t-1) & $-0.363(-0.71)$ & $-0.435(-0.86)$ & $-0.539(-1.11)$ & $-0.646(-1.31)$ \\
\hline Not change employer & $\mathrm{N}=26,111$ & $\mathrm{~N}=25,847$ & $\mathrm{~N}=27,499$ & $\mathrm{~N}=27,256$ \\
\hline Negative shock (t-1) & $0.298(2.99)$ & $0.341(3.31)$ & $0.189(2.10)$ & $0.214(2.23)$ \\
\hline Positive shock (t-1) & $0.012(0.10)$ & $0.032(0.28)$ & $-0.194(-2.13)$ & $-0.288(-3.02)$ \\
\hline age $<40$ & $\mathrm{~N}=12,280$ & $\mathrm{~N}=11,952$ & $N=12,168$ & $\mathrm{~N}=11,853$ \\
\hline Negative shock (t-1) & $0.758(4.70)$ & $0.793(4.76)$ & $0.339(2.11)$ & $0.273(1.62)$ \\
\hline Positive shock (t-1) & $-0.049(-0.27)$ & $-0.033(-0.18)$ & $-0.310(-1.88)$ & $-0.471(-2.78)$ \\
\hline age $>=40$ & $\mathrm{~N}=11,093$ & $\mathrm{~N}=12,141$ & $\mathrm{~N}=10,967$ & $\mathrm{~N}=12,008$ \\
\hline Negative shock (t-1) & $0.090(0.58)$ & $0.182(1.32)$ & $0.111(0.69)$ & $0.244(1.66)$ \\
\hline Positive shock (t-1) & $-0.054(-0.32)$ & $-0.288(-1.99)$ & $-0.049(-0.28)$ & $-0.401(-2.65)$ \\
\hline Manual employee & $\mathrm{N}=9,820$ & $\mathrm{~N}=9,727$ & $\mathrm{~N}=3,702$ & $\mathrm{~N}=3,659$ \\
\hline
\end{tabular}




\begin{tabular}{l|cc|cc} 
Negative shock (t-1) & $0.589(3.11)$ & $0.653(3.33)$ & $0.372(1.19)$ & $0.288(0.87)$ \\
Positive shock (t-1) & $-0.300(-1.38)$ & $-0.258(-1.17)$ & $-0.440(-1.32)$ & $-0.422(-1.19)$ \\
Non-manual & $\mathrm{N}=16,553$ & $\mathrm{~N}=13,408$ & $\mathrm{~N}=20,391$ & $\mathrm{~N}=20,202$ \\
Negative shock (t-1) & $0.326(2.39)$ & $0.329(2.34)$ & $0.256(2.27)$ & $0.273(2.32)$ \\
Positive shock (t-1) & $0.094(0.62)$ & $0.084(0.54)$ & $-0.270(-2.34)$ & $-0.433(-3.65)$ \\
& & & \\
With mortgage & $\mathrm{N}=16,142$ & $\mathrm{~N}=15,981$ & $\mathrm{~N}=16,370$ & $\mathrm{~N}=16,221$ \\
Negative shock (t-1) & $0.263(2.11)$ & $0.346(2.70)$ & $0.282(2.24)$ & $0.292(2.19)$ \\
Positive shock (t-1) & $-0.065(-0.47)$ & $-0.003(-0.02)$ & $-0.155(-1.24)$ & $-0.294(-2.25)$ \\
Without mortgage & $\mathrm{N}=7,231$ & $\mathrm{~N}=7,154$ & $\mathrm{~N}=7,723$ & $\mathrm{~N}=7,640$ \\
Negative shock (t-1) & $0.865(3.62)$ & $0.779(3.13)$ & $0.214(1.07)$ & $0.189(0.91)$ \\
Positive shock (t-1) & $-0.022(-0.08)$ & $-0.117(-0.44)$ & $-0.632(-2.88)$ & $-0.766(-3.43)$ \\
Own outright & $\mathrm{N}=3,305$ & $\mathrm{~N}=3,270$ & $\mathrm{~N}=3,505$ & $\mathrm{~N}=3,460$ \\
Negative shock (t-1) & $0.656(2.06)$ & $0.573(1.76)$ & $0.414(1.72)$ & $0.384(1.56)$ \\
Positive shock (t-1) & $0.095(0.29)$ & $-0.042(-0.12)$ & $-0.628(-2.30)$ & $-0.524(-1.86)$ \\
\hline
\end{tabular}

Note: Control variables including in the regressions consist of financial expectations for the year ahead (2), education dummies (2), age, housing tenure (2), public sector employee and manual worker. 
Table 5: Variation by Borrowing Capacity

\begin{tabular}{|c|c|c|c|c|}
\hline & \multicolumn{2}{|c|}{ MALE } & \multicolumn{2}{|c|}{ FEMALE } \\
\hline & $\begin{array}{c}\text { Total paid hours - } \\
\text { main job }\end{array}$ & $\begin{array}{l}\text { Total paid hours - } \\
\text { including second job }\end{array}$ & $\begin{array}{l}\text { Total paid hours - } \\
\text { main job }\end{array}$ & $\begin{array}{l}\text { Total paid hours - } \\
\text { including second job }\end{array}$ \\
\hline \multicolumn{5}{|c|}{ ALTERNATIVE SAMPLES (with control vector) } \\
\hline $\operatorname{LTV}(\mathrm{t}-1)<0.5$ & $\mathrm{~N}=7,216$ & $\mathrm{~N}=7,144$ & $\mathrm{~N}=7,550$ & $\mathrm{~N}=8,379$ \\
\hline Negative shock (t-1) & $0.218(1.16)$ & $0.309(1.60)$ & $0.458(2.42)$ & $0.448(2.27)$ \\
\hline Positive shock (t-1) & $-0.203(-0.98)$ & $-0.126(-0.59)$ & $-0.0 .037(-0.22)$ & $-0.175(-1.00)$ \\
\hline $\operatorname{LTV}(t-1)>=0.5$ & $\mathrm{~N}=6,855$ & $\mathrm{~N}=6,786$ & $\mathrm{~N}=6,593$ & $\mathrm{~N}=6,542$ \\
\hline Negative shock (t-1) & $0.267(1.41)$ & $0.342(1.75)$ & $0.186(0.93)$ & $0.216(1.01)$ \\
\hline Positive shock (t-1) & $0.188(0.88)$ & $0.245(1.11)$ & $-0.376(-1.87)$ & $-0.564(-2.68)$ \\
\hline $\operatorname{LTV}(t-1)>=0.75$ & $\mathrm{~N}=2,976$ & $\mathrm{~N}=2,950$ & $\mathrm{~N}=2,826$ & $\mathrm{~N}=2,802$ \\
\hline Negative shock (t-1) & $0.232(0.80)$ & $0.335(1.12)$ & $0.179(0.59)$ & $0.089(0.27)$ \\
\hline Positive shock (t-1) & $0.035(0.11)$ & $0.068(0.19)$ & $-0.515(-1.64)$ & $-0.763(-2.34)$ \\
\hline $\begin{array}{l}\text { Problems paying for } \\
\text { housing? Yes. }\end{array}$ & $\mathrm{N}=1,135$ & $\mathrm{~N}=1,123$ & $\mathrm{~N}=1,394$ & $\mathrm{~N}=1,378$ \\
\hline Negative shock (t-1) & $0.722(1.26)$ & $0.548(0.93)$ & $0.438(0.87)$ & $0.264(0.50)$ \\
\hline Positive shock (t-1) & $-0.921(-0.83)$ & $-1.323(-1.19)$ & $-0.082(-0.12)$ & $-0.292(-0.42)$ \\
\hline $\begin{array}{l}\text { Problems paying for } \\
\text { housing? No. }\end{array}$ & $\mathrm{N}=18,194$ & $N=18,016$ & $\mathrm{~N}=18,422$ & $\mathrm{~N}=18,261$ \\
\hline Negative shock (t-1) & $0.435(3.51)$ & $0.510(3.97)$ & $0.206(1.69)$ & $0.199(1.55)$ \\
\hline Positive shock (t-1) & $-0.074(-0.55)$ & $0.009(0.07)$ & $-0.243(-2.00)$ & $-0.439(-3.48)$ \\
\hline
\end{tabular}

Note: LTV samples restricted to homeowners with a mortgage. 
Table 6: Propensity for Labour Market Participation - $y_{i 0}$ exogenous

\begin{tabular}{|c|c|c|c|c|c|c|c|}
\hline & \multicolumn{2}{|c|}{ Male } & \multicolumn{2}{|c|}{ Female } & \multicolumn{3}{|c|}{ Married Women } \\
\hline & {$[1]$} & {$[2]$} & [3] & [4] & {$[5]$} & {$[6]$} & [7] \\
\hline $1 \mathrm{fp}_{\mathrm{t}-1}$ & $2.922(92.03)$ & $2.556(75.04)$ & $2.283(89.30)$ & $2.031(74.08)$ & $2.283(89.30)$ & $1.909(56.77)$ & $1.959(55.70)$ \\
\hline Negative shock ${ }_{t-1}$ & $0.173(5.61)$ & $0.100(3.05)$ & $0.124(5.40)$ & 0.077 (3.18) & $0.124(5.40)$ & $0.071(2.45)$ & \\
\hline Positive shock $\mathrm{t}_{\mathrm{t}-1}$ & $-0.007(-0.20)$ & $-0.072(-1.93)$ & $-0.015(0.58)$ & $-0.027(-0.99)$ & $0.015(0.58)$ & $0.004(0.13)$ & $-0.005(-0.15)$ \\
\hline Spouse lost job ${ }_{\text {it }-1}$ & & & & & & & $-0.106(-1.44)$ \\
\hline Degree-educated & & $0.242(5.02)$ & & $0.378(9.44)$ & & $0.238(4.84)$ & $0.231(4.42)$ \\
\hline A-levels & & $-0.308(-7.24)$ & & $-0.148(-3.97)$ & & $0.067(1.30)$ & $0.101(1.80)$ \\
\hline married & & $0.246(6.13)$ & & $0.040(1.43)$ & & & \\
\hline any child aged $<4$ & & $-0.016(-0.25)$ & & $-0.521(-15.65)$ & & $-0.603(-15.42)$ & $-0.612(-14.28)$ \\
\hline no. of children & & $-0.049(-2.30)$ & & $-0.136(-9.02)$ & & $-0.153(-8.29)$ & $-0.144(-7.10)$ \\
\hline Age dummies & no & Yes (5) & No & Yes (5) & No & Yes (5) & Yes (5) \\
\hline Health dummies & no & Yes (5) & No & Yes (5) & No & Yes (5) & Yes (5) \\
\hline Year dummies & Yes (14) & Yes (14) & Yes (14) & Yes (14) & Yes (14) & Yes (14) & Yes (14) \\
\hline$\rho$ & $0.173(0.021)$ & $0.075(0.020)$ & $0.204(0.016)$ & $0.174(0.017)$ & $0.204(0.016)$ & $0.247(0.020)$ & $0.245(0.022)$ \\
\hline $\begin{array}{l}\text { LR Test }(\rho=0) \\
\text { [p-value] }\end{array}$ & 0.00 & 0.00 & 0.00 & 0.00 & 0.00 & 0.00 & 0.00 \\
\hline Test: $\beta_{1}=\beta_{2}$ & 0.00 & 0.00 & 0.00 & 0.00 & 0.00 & 0.00 & - \\
\hline log likelihood & -6384.662 & -5250.336 & -12333.523 & -11017.055 & -12333.523 & -8156.439 & -7001.094 \\
\hline individuals & 5,292 & 5,292 & 5,996 & 5,996 & 5,996 & 4500 & 4,176 \\
\hline Observations & 34,582 & 34,582 & 39,371 & 39,371 & 39,371 & 28,662 & 24,922 \\
\hline
\end{tabular}

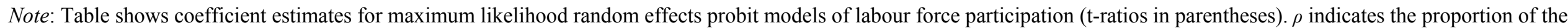
error variance accounted for by the individual-specific component. Test: $\beta_{1}=\beta_{2}$ is a test of the hypothesis of the equality of the two financial shock coefficients. 
Table 7: Propensity for Labour Market Participation - Wooldridge (2005) estimator

\begin{tabular}{|c|c|c|c|c|c|c|c|c|c|}
\hline & \multicolumn{3}{|c|}{ Male } & \multicolumn{3}{|c|}{ Female } & \multicolumn{3}{|c|}{ Married Women } \\
\hline & {$[1]$} & {$[2]$} & Marginal effects & {$[3]$} & {$[4]$} & Marginal effects & {$[5]$} & {$[6]$} & [7] \\
\hline $\mathrm{Lfp}_{\mathrm{t}-1}$ & $1.970(47.92)$ & $1.772(40.34)$ & 0.357 & $1.644(61.73)$ & $1.426(49.75)$ & 0.477 & $1.601(49.55)$ & $1.389(41.00)$ & $1.427(39.26)$ \\
\hline $\operatorname{Lfp}(\mathrm{t}=1)$ & $2.544(24.75)$ & $2.039(21.64)$ & 0.462 & $1.778(33.66)$ & $1.686(32.25)$ & 0.564 & $1.800(23.22)$ & $1.657(27.60)$ & $1.653(25.77)$ \\
\hline Negative shock $_{\mathrm{t}-1}$ & $0.090(2.39)$ & $0.030(0.76)$ & 0.003 & $0.081(3.15)$ & $0.043(1.62)$ & 0.013 & $0.069(2.28)$ & $0.045(1.42)$ & $0.077(2.26)$ \\
\hline Positive shock $\mathrm{t}_{\mathrm{t}-1}$ & $-0.041(-0.96)$ & $-0.084(-1.87)$ & -0.008 & $0.004(0.14)$ & $-0.020(-0.65)$ & -0.006 & $0.016(0.45)$ & $-0.001(-0.02)$ & $0.018(0.47)$ \\
\hline Spouse lost job ${ }_{\text {it }-1}$ & & & & & & & & & $-0.153(-1.94)$ \\
\hline Degree-educated & & $0.739(9.78)$ & 0.043 & & $0.620(12.36)$ & 0.161 & & $0.323(5.61)$ & $0.305(4.98)$ \\
\hline A-levels & & $-0.375(-6.38)$ & -0.042 & & $-0.246(-5.38)$ & -0.082 & & $-0.026(-0.44)$ & $0.004(0.07)$ \\
\hline married & & $0.226(4.11)$ & 0.022 & & $-0.018(-0.53)$ & -0.006 & & & \\
\hline any child aged $<4$ & & $0.017(0.20)$ & 0.001 & & $-0.740(-19.67)$ & -0.265 & & $-0.805(-18.80)$ & $-0.834(-17.68)$ \\
\hline no. of children & & $-0.093(-3.22)$ & -0.008 & & $-0.072(-4.02)$ & -0.023 & & $-0.073(-3.47)$ & $-0.076(-3.32)$ \\
\hline Age dummies & no & Yes (5) & & No & Yes (5) & & No & Yes (5) & Yes (5) \\
\hline Health dummies & no & Yes (5) & & No & Yes (5) & & No & Yes (5) & Yes (5) \\
\hline Year dummies & Yes (14) & Yes (14) & & Yes (14) & Yes (14) & & Yes (14) & Yes (14) & Yes (14) \\
\hline$\rho$ & $0.571(0.019)$ & $0.349(0.025)$ & & $0.390(0.014)$ & $0.174(0.017)$ & & $0.417(0.017)$ & $0.354(0.018)$ & $0.355(0.019)$ \\
\hline $\begin{array}{l}\text { LR Test }(\rho=0) \\
\text { [p-value] }\end{array}$ & 0.00 & 0.00 & & 0.00 & 0.00 & & 0.00 & 0.00 & 0.00 \\
\hline Test: $\beta_{1}=\beta_{2}$ & 0.01 & 0.02 & & 0.02 & 0.07 & & 0.17 & 0.26 & 0.18 \\
\hline log likelihood & -5633.851 & -4687.005 & & -11186.365 & -9957.207 & & -8243.313 & $-7433 . .217$ & -6374.829 \\
\hline individuals & 5,292 & 5,292 & & 5,996 & 5,994 & & 4,500 & 4500 & 4,176 \\
\hline Observations & 34,582 & 34,582 & & 39,371 & 39,368 & & 28,662 & 28,662 & 24,922 \\
\hline
\end{tabular}

Note: Table shows coefficient estimates for maximum likelihood random effects probit models of labour force participation (t-ratios in parentheses), using the Wooldridge (2005) estimator. $\rho$ indicates the proportion of the error variance accounted for by the individual-specific component. Test: $\beta_{1}=\beta_{2}$ is a test of the hypothesis of the equality of the two financial shock coefficients. 
Table 8: Propensity for labour market participation among married women and household balance sheets - Wooldridge (2005) estimator

\begin{tabular}{|c|c|c|c|c|c|c|}
\hline & \multicolumn{3}{|c|}{ Housing tenure } & \multicolumn{3}{|c|}{ Housing equity } \\
\hline & {$[1]$} & {$[2]$} & {$[3]$} & [4] & {$[5]$} & {$[6]$} \\
\hline & mortgagor & Non-mortgagor & Own outright & $l t v<0.4$ & $0.4 \leq l t v<0.65$ & $0.65 \leq l t v$ \\
\hline $1 \mathrm{fp}_{\mathrm{t}-1}$ & $1.228(26.72)$ & $1.637(31.29)$ & $2.059(27.99)$ & $1.819(26.80)$ & $1.045(17.13)$ & $1.181(14.13)$ \\
\hline $\operatorname{lfp}(\mathrm{t}=1)_{\mathrm{i}}$ & $1.557(20.48)$ & $1.597(17.32)$ & $1.361(10.65)$ & $1.240(12.17)$ & $1.428(15.60)$ & $1.337(11.46)$ \\
\hline Negative shock $_{t-1}$ & $0.080(1.98)$ & $0.003(0.06)$ & $-0.027(-0.37)$ & $0.128(2.01)$ & $0.042(0.81)$ & $0.022(0.31)$ \\
\hline Positive shock $\mathrm{t}_{\mathrm{t}-1}$ & $-0.005(-0.11)$ & $0.001(0.01)$ & $0.079(1.00)$ & $0.040(0.56)$ & $-0.053(-0.88)$ & $-0.010(-0.12)$ \\
\hline Degree-educated & $0.249(3.68)$ & $0.308(3.15)$ & $0.046(0.39)$ & $0.214(2.31)$ & $0.221(2.72)$ & $0.154(1.51)$ \\
\hline A-levels & $-0.013(-0.18)$ & $-0.002(-0.02)$ & $0.022(0.17)$ & $0.118(1.04)$ & $-0.085(-1.02)$ & $-0.041(-0.39)$ \\
\hline any child aged $<4$ & $-0.895(-17.54)$ & $-0.690(-8.27)$ & $-0.757(-4.35)$ & $-0.745(-7.82)$ & $-0.937(-15.41)$ & $-0.955(-11.10)$ \\
\hline no. of children & $-0.084(-3.22)$ & $-0.083(-2.29)$ & $0.011(0.18)$ & $0.004(0.11)$ & $-0.123(-3.86)$ & $-0.049(-1.13)$ \\
\hline Age dummies & Yes (5) & Yes (5) & Yes (5) & Yes (5) & Yes (5) & Yes (5) \\
\hline Health dummies & Yes (5) & Yes (5) & Yes (5) & Yes (5) & Yes (5) & Yes (5) \\
\hline Year dummies & Yes (14) & Yes (14) & Yes (14) & Yes (14) & Yes (14) & Yes (14) \\
\hline$\rho$ & $0.353(0.024)$ & $0.355(0.130)$ & $0.283(-3.53)$ & $0.261(0.040)$ & $0.323(0.032)$ & $0.204(0.016)$ \\
\hline LR Test $(\rho=0)$ & 0.00 & 0.00 & 0.00 & 0.00 & 0.00 & 0.00 \\
\hline [p-value] & & & & & & \\
\hline Test: $\beta_{1}=\beta_{2}$ & & & & & & \\
\hline log likelihood & -4343.164 & -3027.318 & -1546.310 & -1743.629 & -2601.452 & -1272.692 \\
\hline individuals & 3,000 & 2,384 & 1,248 & 1,847 & 2,253 & 1,570 \\
\hline Observations & 17,114 & 11,548 & 6,854 & 7,273 & 9,841 & 4,978 \\
\hline
\end{tabular}

Note: Table shows coefficient estimates for maximum likelihood random effects probit models of labour force participation (t-ratios in parentheses), using the Wooldridge (2005) estimator. $\rho$ indicates the proportion of the error variance accounted for by the individual-specific component. Test: $\beta_{1}=\beta_{2}$ is a test of the hypothesis of the equality of the two financial shock coefficients - p-value shown. 


\section{References}

Arulampalam, W (1999), 'A note on estimated effects in random effects probit models', Oxford Bulletin of Economics and Statistics, 61, pp 597-602.

Arulampalam, W and Stewart, M B (2009), 'Simplified implementation of the Heckman estimator of the Dynamic Probit Model and a Comparison with Alternative Estimators', Oxford Bulletin of Economics and Statistics, 71, pp 659-81.

Attanasio, O, Low, $\mathbf{H}$ and Sánchez-Marcos, V (2005), 'Female labour supply as insurance against idiosyncratic risk', Journal of the European Economic Association, Papers and Proceedings, 3, pp 755-64

Benito, A (2009), 'Who withdraws housing equity and why?', Economica, 76, 51-70.

Benito, A (2007), 'Housing equity as a buffer: Evidence from UK households', Bank of England Working Paper No. 324.

Benito, A (2006a), 'The down-payment constraint and UK housing market: Does the theory fit the facts?', Journal of Housing Economics, 15 pp 1-20.

Benito, A (2006b), 'Does job insecurity affect household consumption?', Oxford Economic Papers, 56, pp.157-81.

Benito, A and Mumtaz, H (2009), 'Excess sensitivity, liquidity constraints and the collateral role of housing', Macroeconomic Dynamics, 13, pp.305-26.

Benito, A and Saleheen, J (2011), 'Labour supply as a buffer: Evidence from UK households', Bank of England Working Paper No 426.

Blundell, R (2009), 'From income to consumption: partial insurance and the transmission of inequality', Econometric Society Presidential Lecture.

Blundell, R, Brewer, $M$ and Francesconi, $M$ (2008), 'Job changes and hours changes: Understanding the path of labor supply adjustment', Journal of Labor Economics, 26, pp.421-53.

Blundell, $\mathbf{R}$ and MaCurdy, $\mathbf{T}$ (1999), 'Labor supply: a review of alternative approaches', Chapter 27 in O. Ashenfelter and D. Card (eds.) Handbook of Labor Economics, Elsevier. 
Boheim, $\mathbf{R}$ and Ermisch, J F (2001), 'Partnership dissolution in the UK the role of economic circumstances', Oxford Bulletin of Economics and Statistics, 63, pp 197-208.

Boheim, R and Taylor, M P (2004), 'Actual and preferred working hours', British Journal of Industrial Relations, 42, pp.149-66

Bottazzi, R, Low, H and Wakefield, $\mathbf{M}$ (2007), 'Why do home owners work long hours?', IFS Working Paper 07/10

Bryan, M (2007), 'Free to choose? Differences in the hours determination of constrained and unconstrained workers', Oxford Economic Papers, 59, pp.226-52

Cappellari, L and Jenkins, S P (2009), 'The dynamics of social assistance benefit receipt in Britain', Institute for Social and Economic Research Working Paper No 2009-29, University of Essex.

Carroll, C (1992), 'The buffer stock theory of saving: some macroeconomic evidence' Brookings Papers on Economic Activity

Deaton, A. (1991), 'Saving and liquidity constraints', Econometrica, 59, pp.1,221-45.

French, E (2000), 'The effect of the run-up in the stock market on labor supply', Economic Perspectives, Chicago Fed.

French, E. (2005), 'The effects of health, wealth and wages on labour supply and retirement behaviour', Review of Economic Studies, 72, pp.395-427.

Heckman, J J (1993), 'What has been learned about labor supply in the past twenty years?', American Economic Review, Papers and Proceedings, Vol. 83, pages 116-21.

Heckman, J J (1981), 'The incidental parameter problem and the problem of initial conditions in estimating a discrete time-discrete data stochastic process', in Manski, C F and McFadden, D (eds.) Structural analysis of discrete data with econometric applications, Cambridge, MA, MIT Press.

Henley, A (2004), 'House price shocks, windfall gains and hours of work: British evidence', Oxford Bulletin of Economics and Statistics, 66, pp.439-56 
Hyslop, D (1999), 'State Dependence, Serial Correlation and Heterogeneity in Intertemporal Labor Force Participation of Married Women", Econometrica, 67, pp.1,255-94

Low, H (2005), 'Self-insurance in a life cycle model of labour supply and savings', Review of Economic Dynamics, 8, pp 945-75.

Naylor, R (2002), 'Labour supply, efficient bargains and countervailing power', mimeo, University of Warwick.

Poterba, J (2000), 'The stock market and consumption', Journal of Economic Perspectives, 14, pp.99-118

Stephens, M (2002), 'Worker displacement and the added worker effect', Journal of Labor Economics, 20, pp 504-37

Stewart, M B (2004), 'The impact of the introduction of the UK minimum wage of the employment probabilities of low wage workers', Journal of the European Economic Association, 2, pp.67-97.

Stewart, M (2006), 'Maximum Simulated Likelihood Estimation of Random Effects Dynamic Probit Models with Autocorrelated Errors", Stata Journal, 6, pp.256-72.

Stewart, M and Swaffield, J (1997), 'Constraints on the desired hours of work of British men', Economic Journal, 107, pp.520-35.

Stewart, M and Swaffield, J (2008), 'The other margin: do minimum wages cause working hours adjustments for low-wage workers?', Economica, 75, 148-67.

Wooldridge, J M (2005), 'Simple solutions to the initial conditions problem in dynamic, nonlinear panel data models with unobserved heterogeneity', Journal of Applied Econometrics, 20, pp.39-54 